\title{
The Theoretical Aspect of Pension Reforms, Labor Market and Financial Sector Reforms
}

\author{
Vjollca Sulejmani ${ }^{1} \mathrm{PhD}$
}

\begin{abstract}
The Republic of Macedonia has a good pension system for disability insurance, which is similar in some european countries with more traditional pension system, but this system works in the defined pension regime. The pension system has functioned and functions based on generational solidarity which means that insured persons who are employed pay the pensions for current pensioners hoping that in the future individuals or employees insured and registered in the Invalidity Pension Fund of Republic of Macedonia will pay also for their pensions. The pension system in Macedonia has been applied for almost 50 years but has had some legislative changes and especially in labor legislative, always bearing in mind that these changes have not been created random but they have been created for efficiency in the area of disability pension reforms. Socio-economic changes have affected the system not to be effective and also efficient and adaptable to the population. In early transition the capital market has significantly affected the number of enterprises that have worked with loss and in the end policyholders have finished as redundancy and enterprises have been led to the bankruptcy stage, in the time of transition this was the reason for stagnation because the number of insured people and employees was greater than the number of retirees. All these problems has happened in 1993 and also at same time there were changes in pension and disability insurance law of RM. In early 1997, the new legal changes brought positive effect for the new reform, but what is the main problem of disability pension is that their life expectancy is very short, because of many new laws and obligations that never have foreseen potential risks that may arise in the future. With all these destabilization of the pension system is expected that in 2020 the financial situation of pensions to be stabilized, because an employee who has a pension insurance will fund a pensioner, costs for pensioners will rise and GDP will reach up to $13 \%$. This analysis shows that the RM will not reach to pay pensions for future pensioners according to this law and this phenomenon represents a financial destabilization. These are the reasons for pension and RM pension system reforms for this purpose in 2002 enters into force the law of financing required capital for pensions fund.
\end{abstract}

Keywords: Reforms of pension system, financial capital, minimum risk of pensions, Republic of Macedonia

\section{Introduction}

The Republic of Macedonia has a very good pension disability insurance, it is similar in some European countries more traditional with the pension system, but the system works in defining the pension regime. The pension system has functioned and functions based on generational solidarity which means that the insured persons who are employed, pay their 
pensions to current pensioners hoping that in the future they will be paid by individuals or employees of the insured and registered in the Disability Pension Fund of the Republic of Macedonia. The pension system in Macedonia has done almost 50 years ,but in continuity it has been an interference in the legislative changes and work, always bearing in mind that these changes have not been random, these are created for disability pension reform efficiency of the insured. The socio-economic changes have affected the system to be effective, efficient and also adaptable to the population. At the time of Bismarck, law sanctions in the system of mandatory social insurance raged in social policy, where the system was based on existing institutions of solidarity and mutual aid. The most important element at the time of Bismarck was to achieve a compromise between the three parties, employers, workers and the state, and this avoided the risk of a socialist revolution. At the beginning of transition, the capital market has significantly affected the number of enterprises that have worked with loss, and in the end the insured have ended as technological redundancy and enterprises were led to the bankruptcy stage, in the transition period this was the main reason for lagging because of the great number of the employed and insured comparing to the number of the retirees. All these problems in 1993 were part of the social life and at the same time there were changes in pension and disability insurance law of Republic of Macedonia. In the early 1997, the new legal changes began to be felt and also the positive effects of the new reform, but what is a continuing problem to disability pension is that their life expectancy is very short, because there were brought laws and obligations that have never foreseen potential risks that may arise. With all these destabilizations of the pension system it is expected that in 2020 the financial pension situation stabilizes, because of the reason that an insured pension employer would finance a pensioner, so the costs for pensioners will rise and BPV will reach up to $13 \%$. This analysis shows that the RM will not reach to pay future pensions to pensioners under the law and this phenomenon represents a financial destabilization. These are the reasons of the pension reform and pension system in R.M. For this purpose in 2002 is applied the law for mandatory financial capital of the financial pension fund. The reform provides the improvement of economic policy, indicates the factor of the local growth, collects information on economic development and involves the vital issues of the economic reform. ${ }^{2}$

The goals of the reform are:

-security, which implies the right of the insured disability pension

1 Xhumari, 2012

2 www.mtsp.gov.mk 
- Long-term and short-term security Disability Pension Fund of the Republic of Macedonia

- Maximum safety and minimum risk

- The guaranteed right of pensioners of all generations

- Trust and security for the public pension system through other achievements.

All these goals will result positively in the functioning of the pension system and the economy in general, which affects the reduction of negative social effects (economy market) to the processes of economic restructuring.

\section{The assay of the reform}

The reform bearer is the Ministry of Labour and Social Policy which means that the citizens disability pension system will provide material and social security through III-pillars:

-Pension and disability insurance based on solidarity of the first generation I

-The obligatory pension insurance with financial capital II

-Voluntary pension insurance financing capital III

Pension and Disability Insurance is obliged under the solidarity of generations according to the principle of PAY-AS-YOU-GO, which means insured persons pay current pensions. Through this pillar is ensured the realization of the rights of the security and disability pension in case of aging, disability and death which means they paid their shares. The obligatory pension insurance with insurance capital funding means the capitalization of funds in principle of defined contributions, which implies invested funds of contributions and future pension benefits to which each person carries out from market legitimacy. This type of insurance includes compulsory private pension funds and companies that lead to them.A characteristic of the second pillar pension is that they are led privately which means that the contributions are invested in a company which manages pension fund assets and in this case it increases the strategy investment by investing in limit all funds collected in order to gain that posing risk system investment. Voluntary pension insurance with financial capital is the insurance capital funding of capitalized funds but based on funds invested, a feature of this pillar is that there can be included all persons who are willing to be insured. Each person either employed or not has the right of membership ranging from 15 years to old an age always without considering the value of the investment or the fixed value. ${ }^{3}$ In voluntary insurance take part special social

\footnotetext{
${ }^{3}$ www.mtsp.gov.mk
} 
groups that work abroad ,all individuals over age 15, unemployed persons who needs to obtain a pension under a mandatory scheme, the employer to provide additional income, to create the voluntary scheme where he pays additional contributions and the amount is determined by the employer itself.

The following table presents how the public will be notified of the conditions for joining and functioning of pension pillar II

\begin{tabular}{|c|c|}
\hline If you are: & Then \\
\hline & Obliged membership \\
\hline $\begin{array}{l}\text { Employed for the first time } \\
\text { after January 1, } 2003\end{array}$ & $\begin{array}{l}\text { You are obliged to sign up } \\
\text { with one of the private pension } \\
\text { funds and you can choose in which } \\
\text { fund you wish to become a } \\
\text { member. }\end{array}$ \\
\hline $\begin{array}{l}\text { Employed for the first time } \\
\text { before } 1 \text { January } 2003 \text {, who at the } \\
\text { time of joining }(20.09 .2005- \\
31.12 .2005) \text { were not in working } \\
\text { relations }\end{array}$ & $\begin{array}{l}\text { While membership period } \\
\text { (20.09.2005-31.12.2005) have not } \\
\text { been working relationship, you are } \\
\text { eligible for membership in } \\
\text { voluntary private pension funds } \\
\text { within three months from the date } \\
\text { of reemployment. Membership is } \\
\text { your personal choice and it is your } \\
\text { decision. }\end{array}$ \\
\hline $\begin{array}{l}\text { with less than } 5 \text { years of } \\
\text { experience until the membership }\end{array}$ & $\begin{array}{l}\text { While you are in this } \\
\text { category, and sign up with one of } \\
\text { the private pension funds, will } \\
\text { certainly earn higher pension. }\end{array}$ \\
\hline experience until & $\begin{array}{l}\text { While you are in this } \\
\text { category, and sign up ,you should } \\
\text { know that } 5-7 \text { years of work } \\
\text { experience before joining the } \\
\text { corresponding service of private } \\
\text { pension funds will be accepted } \\
\text { during the calculation of a part of } \\
\text { your pension, which youfrom } \\
\text { would earn SPI Fund. In this case } \\
\text { of course you will earn higher two } \\
\text { pillar pension. }\end{array}$ \\
\hline $\begin{array}{l}\text { with more than } 10 \text { years of } \\
\text { experience until the membership }\end{array}$ & $\begin{array}{l}\text { You need to seriously think } \\
\text { for your decision. There is greater }\end{array}$ \\
\hline
\end{tabular}




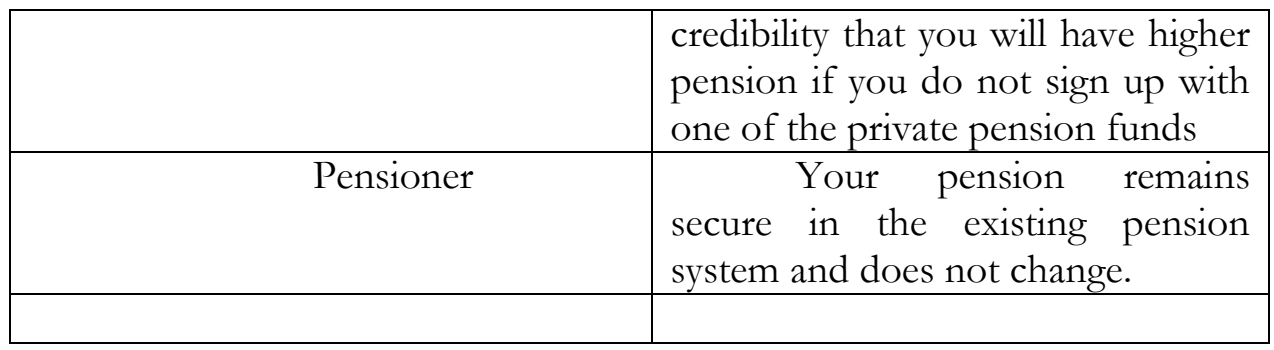

\begin{tabular}{|c|c|}
\hline Categories members & The period of selection \\
\hline \multicolumn{2}{|l|}{ Voluntary members } \\
\hline $\begin{array}{l}\text { Employed for the first time } \\
\text { before } 1 \text { January } 2003 \text {, who have } \\
\text { not been in working relations in the } \\
\text { period of membership }(20.09 .2005- \\
31.12 .2005)\end{array}$ & $\begin{array}{l}\text { Three months from the date } \\
\text { of reemployment }\end{array}$ \\
\hline \multicolumn{2}{|l|}{ Obliged membership } \\
\hline $\begin{array}{l}\text { Employed for the first time } \\
\text { after } 1 \text { January } 2003\end{array}$ & $\begin{array}{l}\text { Three months from the date } \\
\text { of first employment }\end{array}$ \\
\hline
\end{tabular}

From this table we see that each employee has the right to make a choice as to which pension company will be defined and simultaneously signed a contract for a disability pension fund membership.

Before signing, the agents of the company are obliged to present the offer and the membership conditions in case of withdrawal of the contract in a legal deadline of 8 days. The employer has no legal right to oblige his employee and impose the selection of the pension pillar II

\section{The role of economic factor in pension reform dimensions}

An important role plays the open economy and the financial markets in the European Union. It is exactly the capital funding through three pillar pension scheme which has an influence in the diversification of income pension and provides more of the revenue potential of PAYG wherein revenues in such cases neutralize, however, the market must provide the pension scheme and fund with financial well designed capital which plays an important key role in the public opinion and in the investment performance ,and also in motivating the citizen. ${ }^{5}$

${ }^{4}$ www.mtps.gov.mk 


\section{Reforms in labor market}

Looking from this aspect some dilemmas and questions are submitted :

- the number of employees in the labor market is not fixed.

- many pension schemes motivate in early retirement

- application of the labor market by older workers, pensioners exactly

In the Republic of Macedonia labor market is not fixed and it is influenced by many factors such as economic factors, political, and social that this market expands continuously and the number of the employees increases either in the public sector or in a private sector, the labour market has contributed to layer of young people employed to finance people in the stage of aging. Many pension schemes motivate premature retirement every year, every year pensions are reformed and the pension form of the retirement law, precisely at the fulfilled age and conditions of an early retirement or later retirement, which realizes a greater net worth for the purpose of youth employment it is growing continuously since the demand of the labor market by older workers. ${ }^{6}$

\section{Reforms in financial sector}

This trend of pension reform will continue to be applied by other countries of Southeast Europe too through two ways, first way as it exists in Croatia in 2002, Bulgaria 2002, Hungary 1998, Poland in 1999, Romania in 2008 and in Macedonia, is through mandatory pension fund and financed capital fund which these countries apply it in years and the other way is the first pillar which contains third pillar III , which calls pensioners savings tax system that is applied in Germany, Austria, Italy etc. ${ }^{7}$ This market also affects the factor providing funds of supply of commercial banks that are providing various opportunities and offers retirement. For illustration, we have the next 35 years, with an age older than 60 years, this global phenomenon is related to mortality in Macedonia where the number of births is shrinking, ie the number of pensioners is expected to be greater than the number of employees, also here is important the economic stability and reduction of number of employees and the insured, while for financial calculations is very important the number of insured and pensioners because of the contributions of employees and pensioners pay pension. ${ }^{8}$

\footnotetext{
${ }^{6}$ Bar, Dajmond. 2013

${ }^{7}$ www.woldpension.com

${ }^{8}$ www.npf.gov.mk
} 
The number of the insured and the future pensioners is shown in this figure, since this initial period the number of the insured increased as a result of employment and economic development, wherein 2030 will start to reduce the number of the insured as a result of demographic change and economic stability, the number of pensioners in continuity increases and then stabilizes. In the present report 1.6 ensured in one pensioner, where in the future is expected to reach 1 insurer-1 pensioner, this has been the situation that the pension reform was needed because it would come a period which would be needed the value of contributions to increase by lowering the value of pension either through taxes.

\section{References:}

European communities, (2009). Aging report, economic and budgetary projections for the EU-27 member states 2008- 2060. European communities, Luxemburg.

European Bank for Reconstruction and Development, (2009). Transition Report 2009: Transition in crisis? , EBRD.

Fornero, E., (2003). From Pension Design to Pension Reforms. Journal of Europian Social Policy. 13 (3)

Gubbels,J. Snelbecker, D. Zezulin,L The Kosovo Pension Reform: Achievements and Lessons, 2007, siteresources.worldbank.org/SOCIALPROTECTION/Resources/SP-Discussionpapers/Pensions-DP/0707.pdf

Hasa, N. (2005), Pension Funds, Necessity of the Market, interview at Monitor Economic Magazine, 37 (191), Tirana.

Holzmann, R. And Palmer, E. (2006). Pension Reform. ( Issues and Prospects for Non- Financial Defined Contribution (NDC) Schemes). Washington DC. The

Holzmann, R., MacKellar, L. and Repansek, J. (2009). Pension Reform in Southeastern Europe. ( Linking to Labor and Financial Market Reforms). Washington DC, A co publication of the World Bank and the Center of Excellence in Finance.

Merita Vaso Xhumari; 2012: Sistemet pensionale

Petar Bar, Dajmond:2013: Reforma pensionale

Nagip Skenderi:2013: Politika Sociale

www.mapas.gov.mk

www.mtsp.gov.mk

www.npf.gov.mk

www.amf.gov.al

www.tf.ks

www.kbprvo.gov.mk

www.aso.gov.mk 
